\title{
EFFECT OF POLISHING ON THE FATIGUE RESISTANCE AND RESIDUAL STRESSES FOR THE SHOT PEENED OF 7075-T6 ALUMINUM ALLOY
}

\author{
Assist. Prof. Ahmed Naif Ibrahim Al-Khazraji, \\ University of Technology, Department of Mechanical Engineering. \\ E-mail: Drahmed53@yahoo.com \\ Eng. Rasool Mahdi Awwan Al-Shabbani, \\ University of Technology, Department of Mechanical Engineering. \\ E- mail: eng.rma91@yahoo.com
}

Received on 5 April 2017 Accepted on 31 October 2017 Published on 30 December 2017 DOI: 10.30772/qjes.v10i4.491

\begin{abstract}
Aluminum alloy (7075-T6) is widely used in various industries in parts of aircraft, automobiles and other mechanical applications. It is known that the process of the shot peening leads to an increase in the value of residual stresses, which prolong the fatigue life. However, during surface peening of various metals, including aluminum alloy (7075T6) used in this work, these surfaces become rough where the places to concentrate the stresses, which will fail when exposed to different dynamic stresses. This paper presents an study on the effect of polishing (the roughness surface induced from shot peening process) on endurance limit and residual stresses result by shot peening. In this paper was used three values of surface roughness $(1.5,3$, and 5) $\mu \mathrm{m}$. The obtained results show that the maximum increasing in endurance limit was (53\%) at low roughness compared with as received and increasing value roughly to (27\%) compared with alloy after shot peening. . The residual stresses gradually increased (-222.735, -229.602, -250.900) Mpa when the roughness surfaces decreased $(5,3,1.5) \mu \mathrm{m}$ respectively.
\end{abstract}

Keywords: polishing Shot peening, Residual stress, Endurance limit, Aluminum alloy (7075-T6).

\section{INTRODUCTION}

Aluminum alloys are an attractive class of materials because of their high specific static strength. Usually, high static mechanical properties are induced in aluminum alloys by dispersion hardening through solution and ageing heat treatments [1, 2]. Al alloys are frequently subjected to surface treatments in order to improve their plain and notch fatigue strength. Among them, shot peening is one of the most widely used. This process consists of bombarding the component with small spherical shots of a hard material at a relatively high velocity. The multiple indentation of the ductile target surface increases its surface roughness and causes localized plastic deformation, which in turn results in work-hardening and introduction of a inplane compressive residual stress field in the surface layers [3,4].

Components are regularly subjected to dynamic loads, which make them prone to fatigue failure. It is a well-known fact that almost all fatigue cracks form at the surface due to a variety of surface stress 


\section{AL-QADISIYAH JOURNAL FOR ENGINEERING SCIENCES}

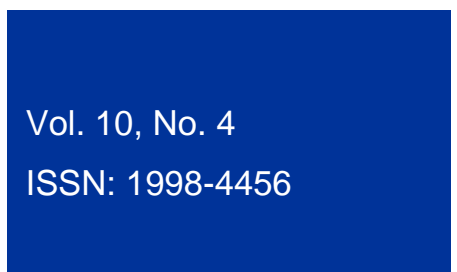

concentration failures. Evidently, the control of surface initiation and growth of cracks is an effective means of enhancing the fatigue endurance of metallic components [5,6]. The results showed that obtained from the positive influence of the shot Peening treatment on the fatigue properties as caused by hardened surface layer and compressive residual stresses delayed the initiation of fatigue cracks. Shot peening treatment nearly doubled the cycles to failure at the higher applied stresses when compared to the untreated specimens [7]. Aggressive shot peening tends to increase the surface roughness which can be detrimental to fatigue performance. The higher roughness creates short crack growth and reduce the fatigue life [8]. The fatigue life reduction factor (LRF) due to the aggressive shot peening was established and empirical relations were proposed to describe the behavior of LRF, roughness and fatigue life [9].

In this paper, the effect of surface polishing of the shot peening aluminum alloy (7075-T6) on the residual stresses and endurance limit is studied. Because the shot peening surfaces of the aluminum alloy lead to the creation of roughness on the surfaces, which generates the concentration of stresses in some rough places, when exposed to dynamic loads will descend the ages of the functionality of these pieces because of the concentration of stresses. The rough surfaces were polished with three different degrees $(5$, $3,1.5 \mu \mathrm{m})$, and the study of the change of the residual stresses on the surfaces after being polished, as well as the effect of this polishing on the change endurance limit for the selected alloy.

\section{EXPERIMENTAL WORK}

\subsection{MATERIAL}

The materials used in this study is 7075-T6 aluminum alloys, low-specific weight and high strength to weight ratio and also high electrical and thermal conductance. This alloy is widely used in industry and in particular in aircraft structure and pressure vessels. The main alloying element in the 7XXX series is $\mathrm{Zn}$, while $\mathrm{Mg}$ and $\mathrm{Cu}$ are also introduced in order to improve the properties [10]. The chemical analysis of this alloy is in Table (1) and the Mechanical Properties is presented in Table (2) .

Table 1: Chemical composition of 7075-T6 aluminum alloy.

\begin{tabular}{|c|c|c|c|c|c|c|c|c|c|}
\hline $\begin{array}{c}\text { Percentage } \\
\text { Composition }\end{array}$ & $\begin{array}{c}\mathrm{Si} \\
\%\end{array}$ & $\begin{array}{c}\mathrm{Fe} \\
\%\end{array}$ & $\begin{array}{c}\mathrm{Cu} \\
\%\end{array}$ & $\begin{array}{c}\mathrm{Mn} \\
\%\end{array}$ & $\begin{array}{c}\mathrm{Mg} \\
\%\end{array}$ & $\begin{array}{c}\mathrm{Zn} \\
\%\end{array}$ & $\begin{array}{c}\mathrm{Cr} \\
\%\end{array}$ & $\begin{array}{c}\mathrm{Ti} \\
\%\end{array}$ & $\begin{array}{c}\mathrm{Al} \\
\%\end{array}$ \\
\hline $\begin{array}{c}\text { Nominal } \\
\text { [ASM] }^{[11]}\end{array}$ & $\begin{array}{c}0.4 \\
\mathrm{max}\end{array}$ & $\begin{array}{c}0.5 \\
\mathrm{max}\end{array}$ & $\begin{array}{c}1.2- \\
2\end{array}$ & 0.3 & $\begin{array}{c}2.1- \\
2.9\end{array}$ & $\begin{array}{c}5.1- \\
6.1\end{array}$ & $\begin{array}{c}0.18- \\
0.28\end{array}$ & 0.2 & Balance \\
\hline Measured & $\begin{array}{c}0.01 \\
67\end{array}$ & $\begin{array}{c}0.05 \\
5\end{array}$ & 1.69 & $\begin{array}{c}0.01 \\
1\end{array}$ & 2.59 & 5.68 & $\begin{array}{c}0.21 \\
7\end{array}$ & $\begin{array}{c}0.02 \\
8\end{array}$ & Balance \\
\hline
\end{tabular}

Table 2: Mechanical Properties

\begin{tabular}{|c|c|c|c|c|}
\hline $\begin{array}{c}\text { Modulus of } \\
\text { Elasticity } \\
\text { GPa }\end{array}$ & $\begin{array}{c}\text { Hardness, } \\
\text { Vickers }\end{array}$ & $\begin{array}{c}\text { Elongation at } \\
\text { Break } \\
\%\end{array}$ & $\begin{array}{c}\text { Tensile Yield } \\
\text { Strength } \\
\text { Mpa }\end{array}$ & $\begin{array}{c}\text { Ultimate } \\
\text { Tensile } \\
\text { Strength } \\
\mathrm{MPa}\end{array}$ \\
\hline 74 & 152 & 10.1 & 483 & 521 \\
\hline
\end{tabular}




\section{AL-QADISIYAH JOURNAL FOR ENGINEERING SCIENCES}

Vol. 10, No. 4

ISSN: $1998-4456$

\subsection{PREPARATION OF SAMPLES}

Two types of specimens were prepared in this study; one for tensile test were prepared according to standards of ASTM E8, see Figure 1. And the other is for the fatigue tests were prepared according to machine specifications [12], see Figure 2. Specimens manufacturing process was done by using a programmable CNC Milling (C-tek) machine.

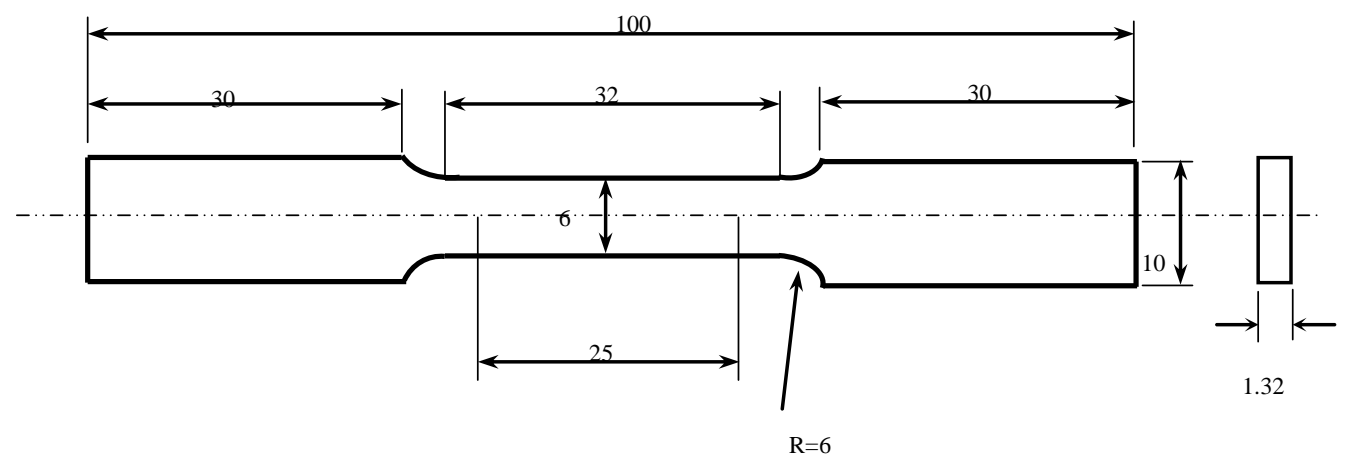

Figure 1: Specimen geometry and dimensions for tensile test (all dimensions in mm) According to ASTM E8.

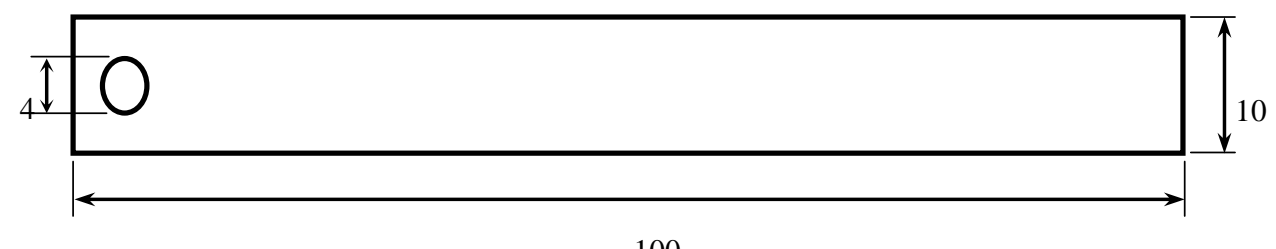

100

Figure 2: Specimen geometry and dimensions for fatigue test (all dimensions in $\mathrm{mm}$ ) According to machine specifications [9].

\subsection{SHOT PEENING}

The shot peening is accomplished by machine of Sintokogio LTD, model STB-OB. In this machine, the motor rotates an impeller which bombard the shots towards the specimens at 1435 r.p.m motor rotational speed with one jet of shots at an average speed of $70 \mathrm{~m} / \mathrm{s}$. The material of the shooting balls is a low carbon steel with average diameter of $1.2 \mathrm{~mm}$ and coverage of $80-100 \%$. The peening machine consist of rotary cylinder with inside diameter of $590 \mathrm{~mm}$ and depth of $740 \mathrm{~mm}$ in which the specimens is placed. Both tensile and fatigue specimens were subjected to shot peening. The time used for shot peening was (12min), this optimum time for AA 7075-T6 taking from reference [13], see Figure 3. 


\section{AL-QADISIYAH JOURNAL FOR ENGINEERING SCIENCES}

Vol. 10, No. 4

ISSN: $1998-4456$

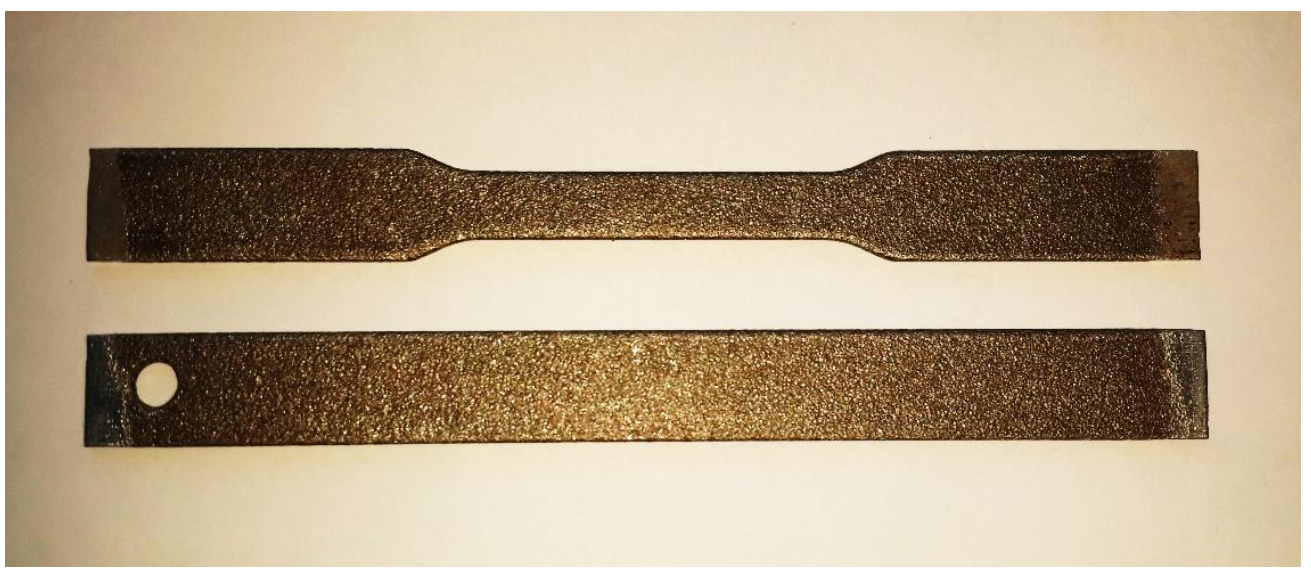

Figure 3: tensile test specimen and fatigue test specimen after shot peened process.

\subsection{POLISHING OF SPECIMENS}

After shot peening Process, specimens were prepared using the silicon carbide papers as $(200,400$, $800)$ to make three values of surface roughness, they are $(5,3,1.5) \mu \mathrm{m}$ respectively, using surface roughness testing machine type DIAVITE DH-7.

\subsection{TENSILE TEST}

The type of used tensile test machine was microcomputer controlled electronic universal testing machine Tinius Olsen H50KT. Tensile tests were done before and after shot peening and for all stages of the polishing process. Three specimens were tested for each case and taking the average value to satisfy an additional accuracy.

\subsection{FATIGUE TEST}

The type of fatigue testing machine used in this work was HI-TECH alternating bending fatigue (HSM20) with constant amplitude loading.

A series of tests are commenced by acting a specimen to the stress cycling and the number of cycles to failure is counted. This procedure is repeated on other specimens at progressively decreasing stress amplitudes. As a result, the surfaces of the specimens are under tension and compression stresses when the specimen fluctuated. All the tests done at constant stress amplitude loading with $R=-1$. The obtained data were plotted as stress $S$ versus the logarithm of the number $N$ of cycles to failure for each of the specimens.

\section{RESULTS AND DISCUSSION}

\subsection{TENSILE TEST RESULTS}

To obtain the mechanical properties, the tensile tests of the chosen material 7075-T6 aluminum alloys were performed to obtain the values of the ultimate tensile stress $\sigma_{u}$, yield stress $\sigma_{y}$ and elongation $E \%$. 


\section{AL-QADISIYAH JOURNAL FOR ENGINEERING SCIENCES}

Vol. 10, No. 4

ISSN: $1998-4456$

Table (3) , lists the tensile values for the as received, after shot peening and polishing proses compared to the American Society for Testing and Materials specifications (ASTM) at room temperature.

The results of tensile tests showed that the ultimate tensile strength has a small increasing according to shot peening effect, but the amount of increasing depends on the compressive residual stress and variation with it. The maximum percentage changes of ultimate tensile is $(7.485 \%)$ for aluminum alloy 7075 T6 polishing for surface roughness $(\mathrm{Ra}=1.5 \mu \mathrm{m})$.

Table 3: Tensile tests results

\begin{tabular}{|c|c|c|c|}
\hline Alloy type & Condition & $\sigma_{u}(\mathrm{MPa})$ & $\sigma_{y}(\mathrm{MPa})$ \\
\hline $7075-\mathrm{T6}$ & Standard & 573 & 504 \\
\hline $7075-\mathrm{T6}$ & Received & 521 & 483 \\
\hline $7075-\mathrm{T} 6$ & Shot peening & 533 & 491 \\
\hline $7075-\mathrm{T} 6$ & $\mathrm{Ra}=5 \mu \mathrm{m}$ & 545 & 496 \\
\hline $7075-\mathrm{T} 6$ & $\mathrm{Ra}=3 \mu \mathrm{m}$ & 554 & 501 \\
\hline $7075-\mathrm{T6}$ & $\mathrm{Ra}=1.5 \mu \mathrm{m}$ & 560 & 506 \\
\hline
\end{tabular}

\subsection{S-N CURVE}

The S-N curves were obtained from the fatigue tests for all specimens as received, shot peening and polishing process after shot peening at surface roughness $\mathrm{Ra}(5,3,1.5) \mu \mathrm{m}$, see Figures $(4,5)$. From these data, the fatigue life estimation equations were obtained, the endurance limit at $\mathrm{N}_{f}=10^{6}$ cycles.

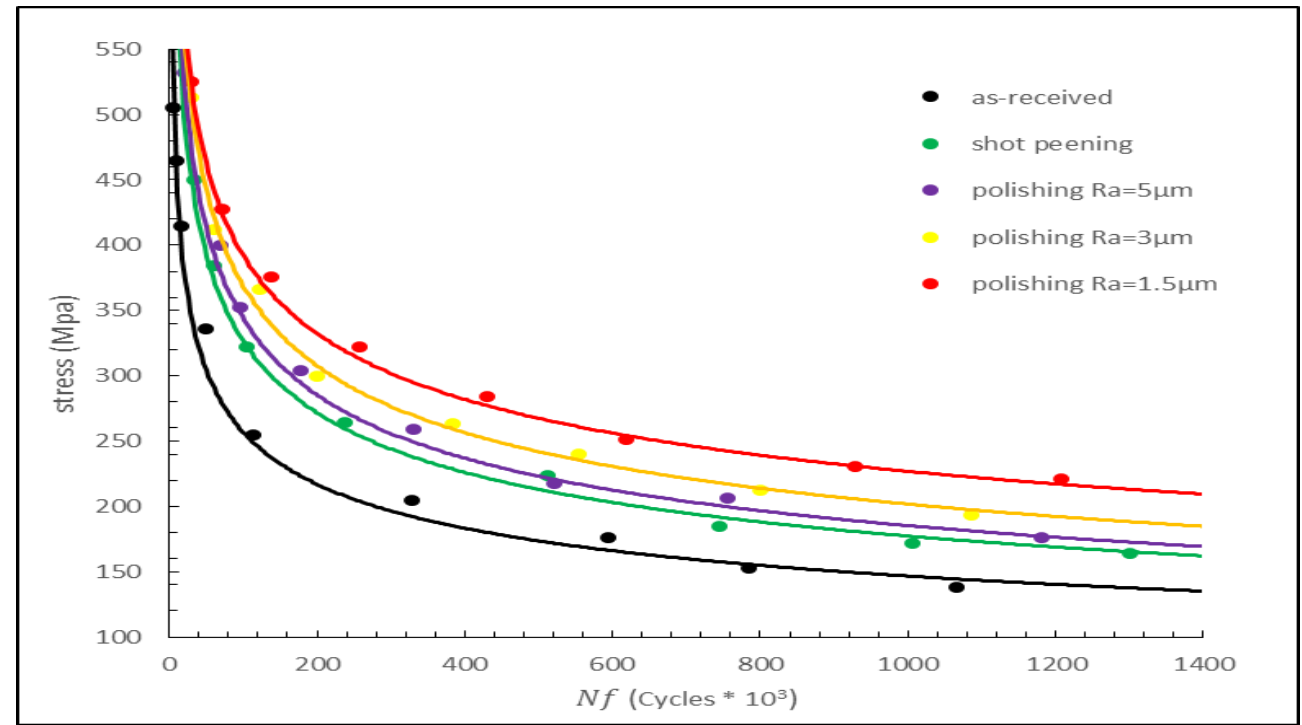

Figure 4: S-N curve for 7075-T6 aluminum alloy. 


\section{AL-QADISIYAH JOURNAL FOR ENGINEERING SCIENCES}

Vol. 10 , No. 4

ISSN: 1998-4456

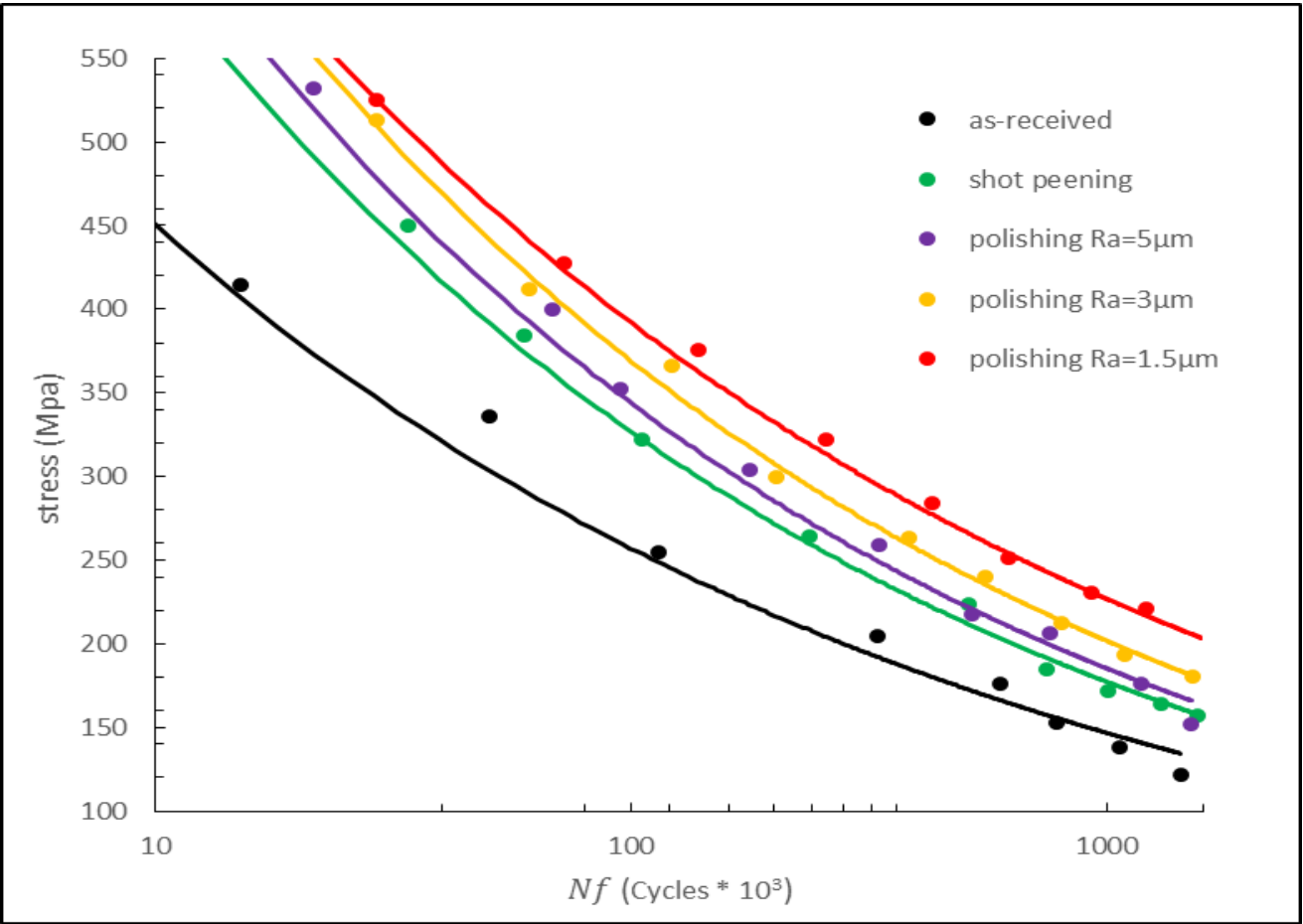

Figure 5: Semi log S-N curve for 7075-T6 aluminum alloy.

From the results of the fatigue test of polishing process (for three stages), it can be observed that the value of the endurance limit of this process is higher than the value of endurance limit of shot peening, that's due to the effect of the compressive residual stresses and roughness surface was decreased.

The equations and fatigue strength which describes this curve are given in Table (4).

Table 4: S-N curved equations for 7075-T6 T6 aluminum alloy.

\begin{tabular}{|c|c|c|c|c|}
\hline Condition & $\begin{array}{l}\text { Surface roughness } \\
\qquad \operatorname{Ra}(\mu \mathrm{m})\end{array}$ & S-N curve equation & $\begin{array}{l}\sigma_{E: L .} \\
(\mathrm{Mpa})\end{array}$ & $\begin{array}{c}\text { Increase in } \\
\sigma_{E \cdot L . L_{x}} \%\end{array}$ \\
\hline Received & $\mathrm{Ra}=0.19$ & $\sigma_{E . L_{.}}=4237.4 N_{f}^{-0.243}$ & 147.6 & - \\
\hline shot peening & $\mathrm{Ra}=6.093$ & $\sigma_{E . L_{.}}=6934.6 N_{f}^{-0.265}$ & 178.25 & 20.765 \\
\hline \multirow{3}{*}{$\begin{array}{l}\text { Polishing } \\
\text { process }\end{array}$} & $\mathrm{Ra}=5$ & $\sigma_{E, L_{L}}=7553.9 N_{f}-0.268$ & 186.28 & 26.206 \\
\hline & $\mathrm{Ra}=3$ & $\sigma_{E L_{L}}=7548.6 N_{f}-0.262$ & 202.24 & 37.02 \\
\hline & $\mathrm{Ra}=1.5$ & $\sigma_{E, L}=6046 N_{f}-0.238$ & 225.67 & 52.892 \\
\hline
\end{tabular}




\section{AL-QADISIYAH JOURNAL FOR ENGINEERING SCIENCES}

Vol. 10, No. 4

ISSN: $1998-4456$

$\sigma_{\mathrm{E}, \mathrm{L}}-\mathrm{Ra}$ curve of laboratory specimens are presented in Figure (6). The experimental equations of Surface roughness and Endurance limit can be shown in Table (4) for polishing process. The relation between Surface roughness and Endurance limit can be described by the formula (1)...

$$
\sigma_{\mathrm{E} . \mathrm{L} \mathrm{a}}=543.52(R a+4.316)^{-0.498}
$$

From Figure (6), the endurance limit is increasing due to decreased of surface roughness in addition to the presence of residual stresses, the maximum value of endurance limit is $(52.892 \%)$ at less surface roughness $(\mathrm{Ra}=1.5 \mu \mathrm{m})$.

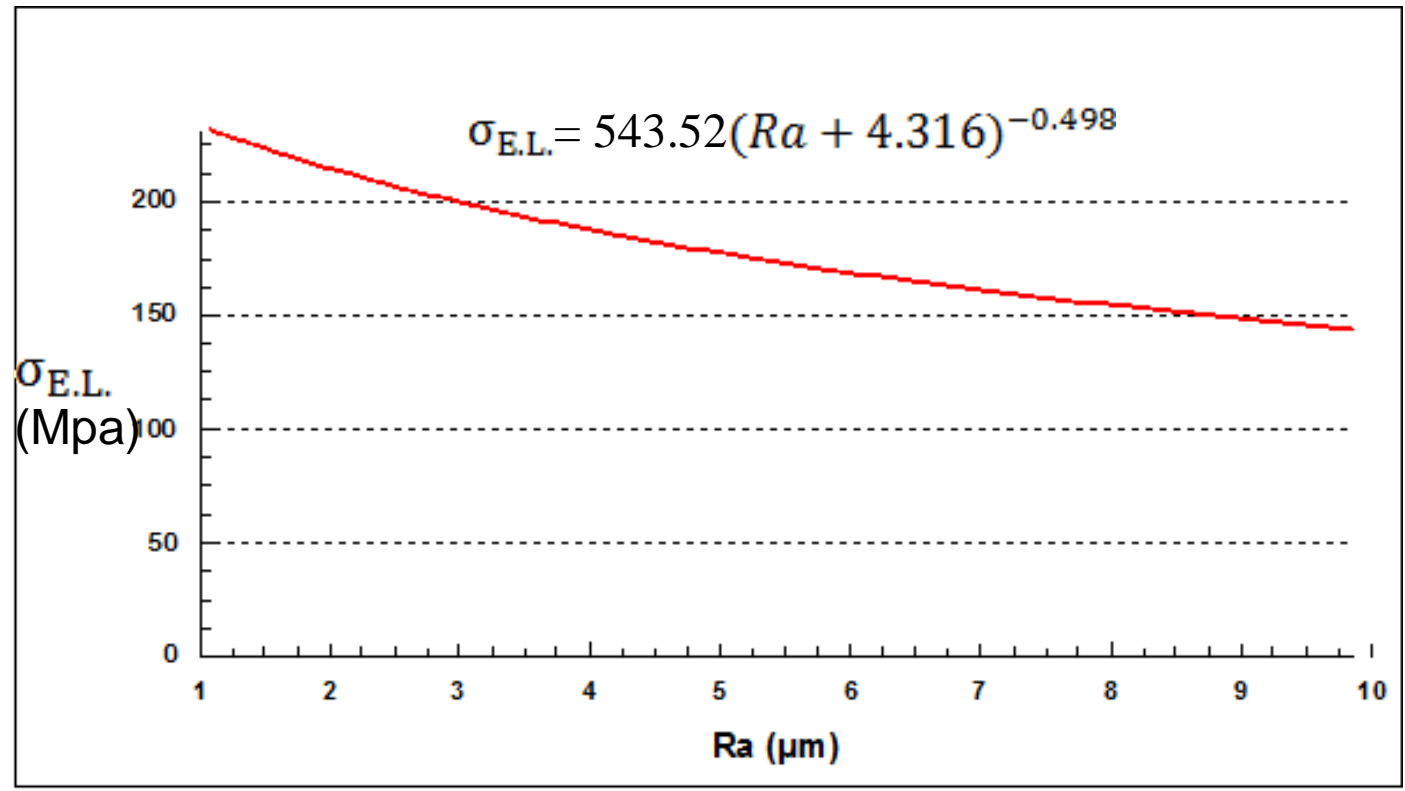

Figure 6: $\sigma_{\mathrm{E}, \mathrm{L} .}-$ Ra curve for polishing process.

\subsection{RESIDUAL STRESS}

The X-Ray diffraction (XRD) measurements of the residual stress on the surface were taken by using machine type Lab6000, Figure (7), with stress analysis adapter before and after shot peening and polishing process of specimens, the result are shown in the Table (5).

$\sigma_{\text {res }}-$ Ra curve of laboratory specimens are presented in Figure (8). The experimental equations of Surface roughness and Residual stress can be shown in Table (5) for polishing process.

The relation between Surface roughness and Residual stress can be described by the formula (2)... 
AL-QADISIYAH JOURNAL FOR ENGINEERING SCIENCES
Vol. 10, No. 4

ISSN: 1998-4456

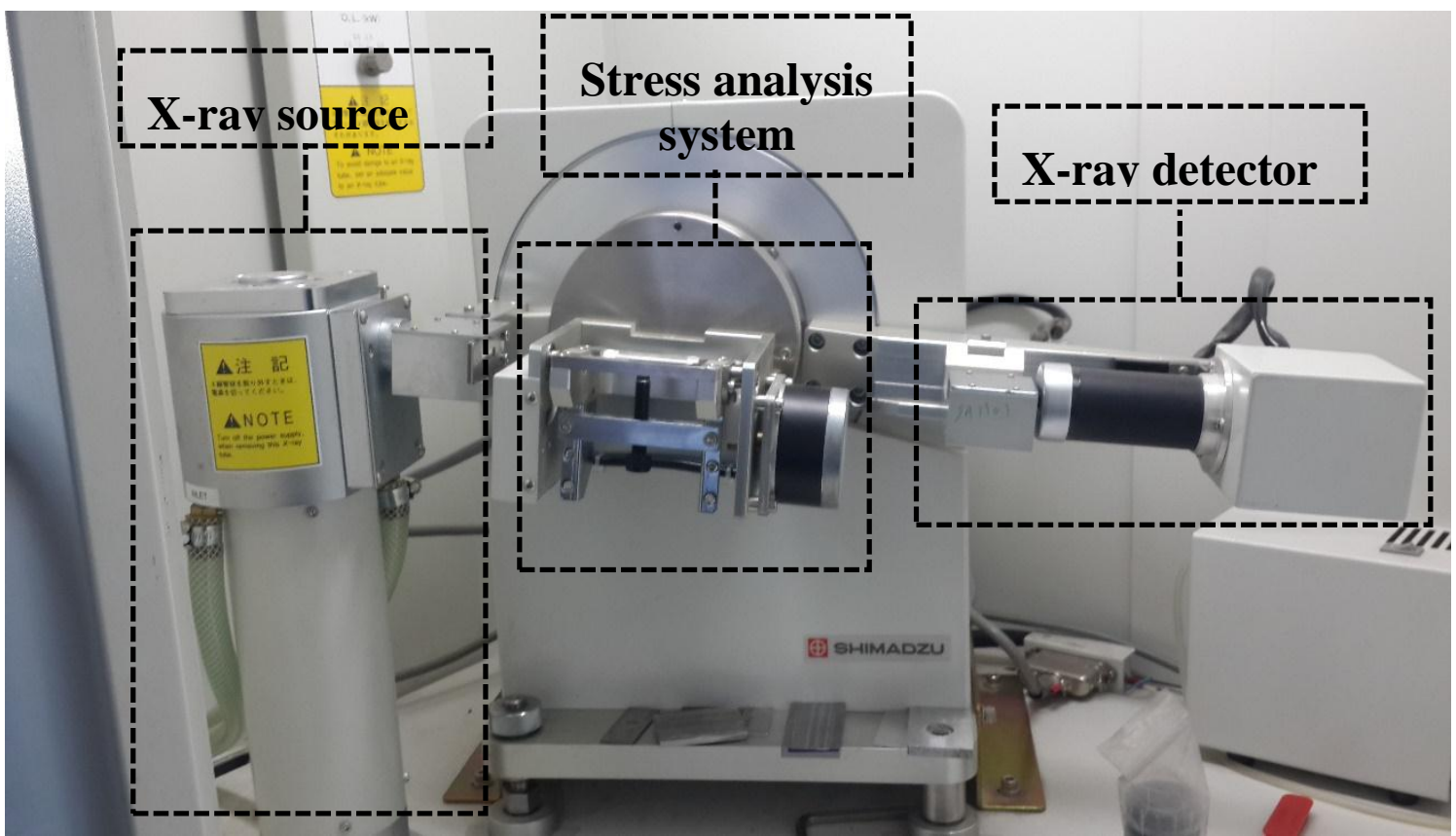

(A)

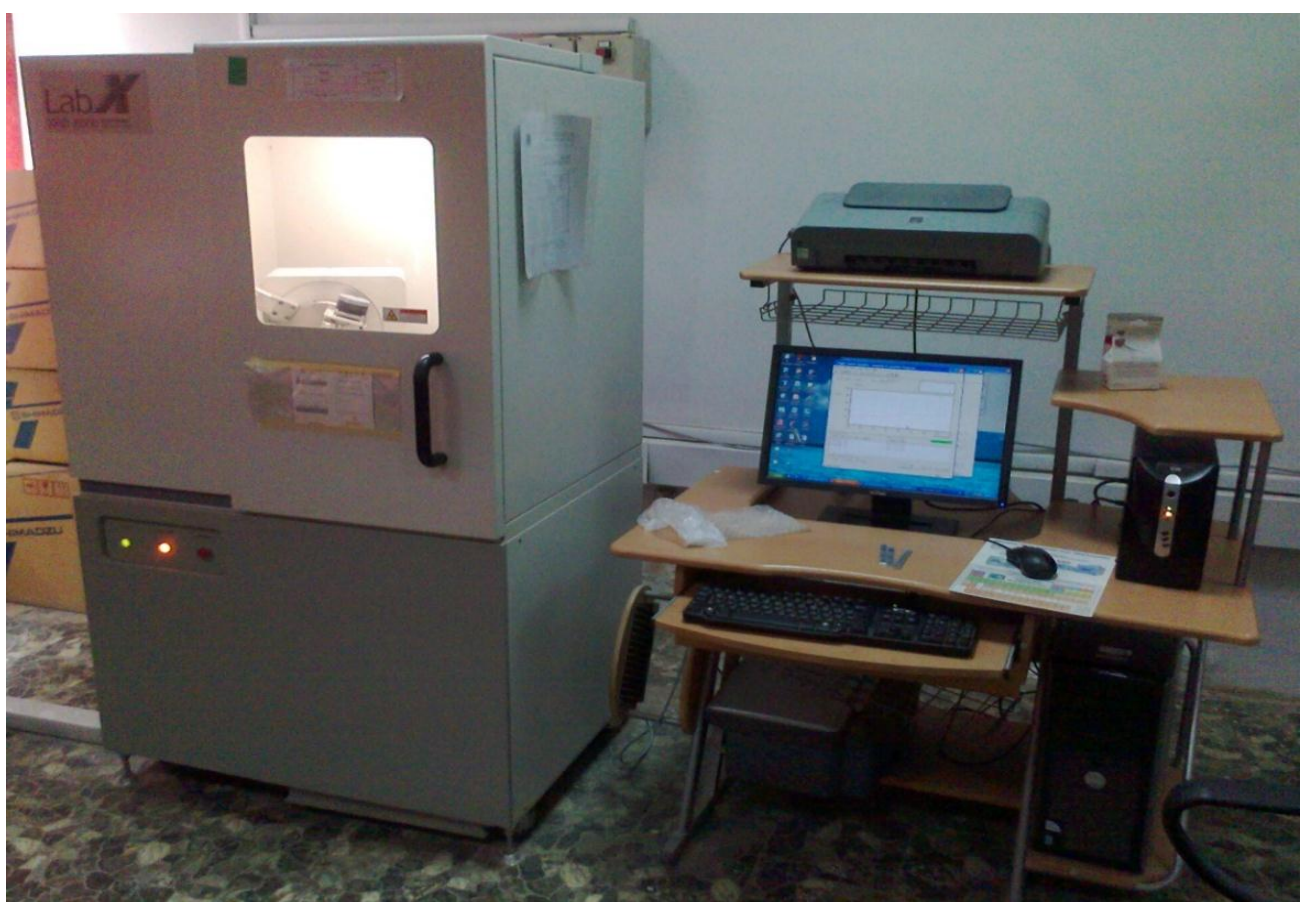

(B)

Figure 7: A- X-ray diffraction (XRD) machine type Lab-6000 \& B- XRD machine with specialized stress analysis system 


\section{AL-QADISIYAH JOURNAL FOR ENGINEERING SCIENCES}

Vol. 10 , No. 4

ISSN: $1998-4456$

$$
\sigma_{\text {res }}=\frac{-220.9178}{1-0.3775 e^{-0.767 R a}}
$$

From Figure (8), the residual stresses gradually increasing when the roughness surfaces decreasing, this shows that the residual stresses are generated by shot peening process at, or just below the surface layer for a certain depth and usually it is higher that on the surface.

Table 5: Experimental residual stresses results for 7075-T6 aluminum alloy.

\begin{tabular}{|c|c|c|}
\hline Condition & $\begin{array}{c}\text { Surface roughness } \\
\mathrm{Ra}(\mu \mathrm{m})\end{array}$ & $\begin{array}{c}\sigma_{\text {res }} \\
(\mathrm{Mpa})\end{array}$ \\
\hline \multirow{2}{*}{ Received } & $\mathrm{Ra}=0.19$ & -3.477 \\
\hline \multirow{2}{*}{ shot peening } & $\mathrm{Ra}=6.093$ & -263.527 \\
\hline \multirow{2}{*}{$\begin{array}{c}\text { Polishing } \\
\text { process }\end{array}$} & $\mathrm{Ra}=5$ & -222.735 \\
\cline { 2 - 3 } & $\mathrm{Ra}=3$ & -229.602 \\
\cline { 2 - 3 } & $\mathrm{Ra}=1.5$ & -250.900 \\
\hline
\end{tabular}

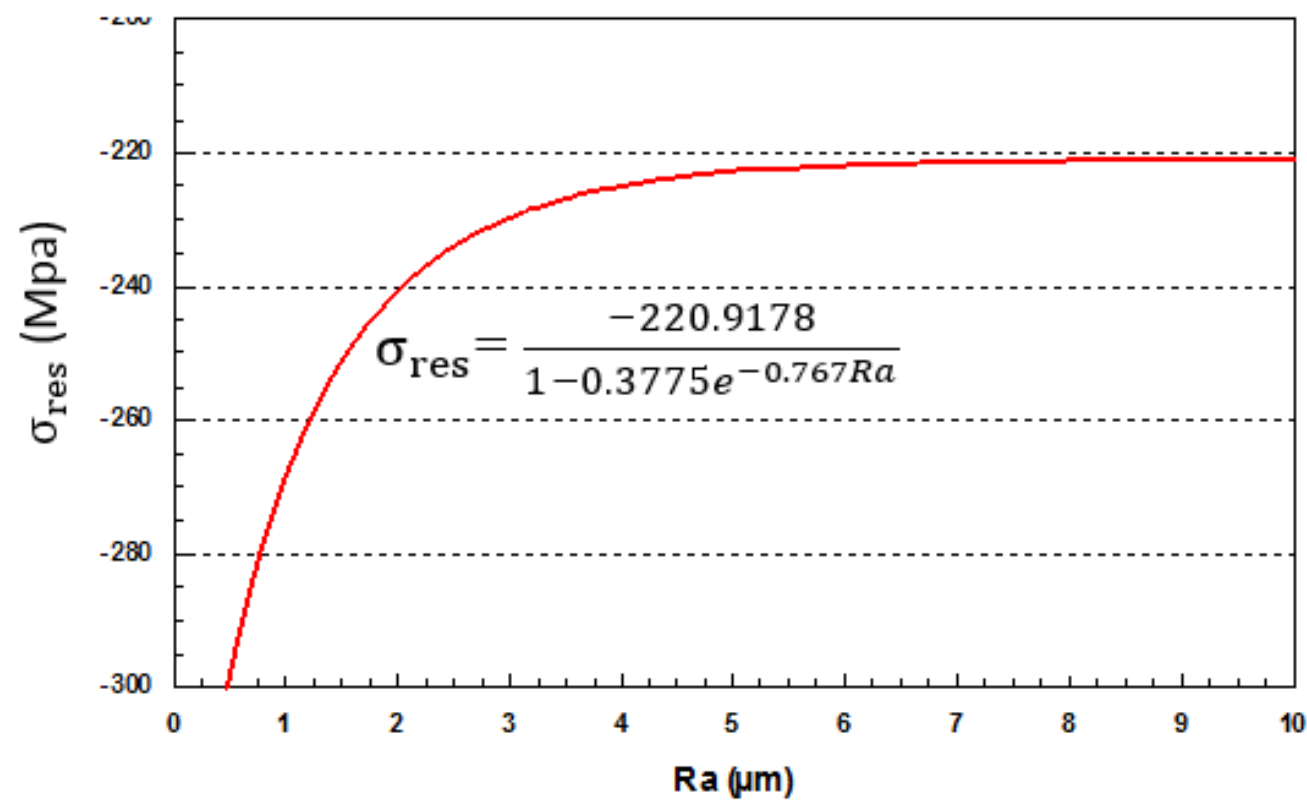

Figure 8: $\sigma_{\text {res }}-$ Ra curve for polishing process 


\section{AL-QADISIYAH JOURNAL FOR ENGINEERING SCIENCES}

Vol. 10, No. 4

ISSN: $1998-4456$

\section{CONCLUSIONS}

The main conclusions drawn from this paper are :

1. After polishing (for less surface roughness $\mathrm{Ra}=1.5 \mu \mathrm{m}$ ), The maximum enhancement percentage $(53 \%)$ of the endurance limit was obtained compared with as received material.

2. While the max. improvement carried out of $(27 \%)$ in the endurance limit at same roughness $(\mathrm{Ra}=1.5 \mu \mathrm{m})$ compared with shot peened specimen.

3. The residual stresses were increased as surface roughness decreased in polishing process.

4. A small improvement obtained in some mechanical properties such as ultimate tensile stress $\left(\sigma_{u}\right)$ which was $(7.485 \%)$ compared with as received at high smoothing $(\mathrm{Ra}=1.5 \mu \mathrm{m})$.

5. It was obtained from this study two math. models to calculate the endurance limit \& surface roughness and the $2^{\text {nd }}$ model to calculate the residual stresses \& surface roughness such as :

$$
\sigma_{\mathrm{E} . \mathrm{Lu}}=543.52(R a+4.316)^{-0.498} \quad \& \quad \sigma_{\mathrm{res}}=\frac{-220.9178}{1-0.3775 e^{-0.767 R a}}
$$

\section{REFERENCES}

1. M. Benedetti, V. Fontanari, M. Bandini and D. Taylor, "Mu'ltiaxial fatigue resistance of shot peened high-strength Aluminum alloys" International Journal of Fatigue Vol.61, pp.271-282, 2014.

2. Fatemi A, Plaseied A, Khosrovaneb AK, Tanner D., "Application of bi-linear log- $\log S-N$ model to strain-controlled fatigue data of aluminum alloys and its effect on life predictions". Int J Fatigue, Vol.27, pp.1040-1050, 2005.

3. Benedetti M, Fontanari V, Santus C, Bandini M., "Notch fatigue behaviour of shot peened high-strength aluminium alloys: experiments and predictions using a critical distance method". Int J Fatigue, Vol.32, pp.1600-1611, 2010.

4. Guechichi H, Castex L., "Fatigue limits prediction of surface treated materials". J Mater Proc Technol Vol.172, pp.381-387, 2006.

5. Hussain J. Al-Alkawi, Qusay K. Mohammed and Waleed S. Al-Nuami, "The Effect of Shot Peening and Residual Stresses on Cumulative Fatigue Damage", Engineering and Technology Journal, Vol. 28,Issuo 15, pp.5055-5071, 2010.

6. K.J. Miller, "Materials Science perspective of metals fatigue resistance" Material Science and Technology, Vol. 9 pp 453-462, 1993.

7. Uroš Zupanc and Janez Grum, "Surface Integrity of Shot Peened Aluminum Alloy 7075-T651" University of Ljubljana, Faculty of Mechanical Engineering, Slovenia, Journal of Mechanical Engineering 57(5), 379384, 2011.

8. Y. Fouad and Mostafa M. EI Metalally, "Effect of shot peening on high cycling fatigue of Al 2024-T4", International conference on advanced materials engineering IPCSIT vol. 15, 2011.

9. Khairallah S. Jabur, "Analysis of the Effects of Aggressive Shot Peening on Fatigue Life of 7075 -T6 Aluminum Alloy", Al-Khwarizmi Engineering Journal, Vol. 8, No.4, pp. 90- 95, 2012. 


\section{AL-QADISIYAH JOURNAL FOR ENGINEERING SCIENCES}

Vol. 10, No. 4

ISSN: $1998-4456$

10. ASTM, "Standard Specification for Aluminum and Aluminum-Alloy Sheet and Plate ", B 209-00, 2006.

11. G. H. Majzoobi, J. Nemati , A. J. N. Rooz, G. H. Farrahi, "Modification of fretting fatigue behavior of AL7075- T6 alloy by the application of titanium coating using IBED technique and shot peening" ,Tribology International, Vol.42, pp.121-129, 2009.

12. N. P. Roberts and Nigel R. Hart, "Alternating Bending Fatigue Machine (HSM20), Instruction Manual", Hi-Tech Ltd. UK. , 2001.

13. Ahmed N. Al-Khazraji and Thamer A. AL-Taie, "The effect of shot peening on the notch sensitivity factor and Neuber characteristic length for 7075-T6 Aluminum alloy",Journal of Engineering and Development, Vol.19, No.4, ISSN 1813- 7822, 2015. 